\title{
Micropropagation and Production of Somatic Seeds for Short-Term Storage of the Endangered Species Eryngium alpinum L.
}

\author{
Małgorzata Kikowska $^{1, *\left(\mathbb{D}, \text { Elwira Sliwinska }^{2}(\mathbb{D}) \text { and Barbara Thiem }\right.}{ }^{1}$ \\ 1 Department of Pharmaceutical Botany and Plant Biotechnology, University of Medical Sciences in Poznan, \\ 14 Św. Marii Magdaleny St., 61-861 Poznań, Poland; bthiem@ump.edu.pl \\ 2 Laboratory of Molecular Biology and Cytometry, Department of Agricultural Biotechnology, \\ UTP University of Science and Technology, Prof. S. Kaliskiego Ave. 7, 85-789 Bydgoszcz, Poland; \\ elwira@utp.edu.pl \\ * Correspondence: kikowska@ump.edu.pl; Tel.: +48-616-687-850
}

Received: 2 March 2020; Accepted: 9 April 2020; Published: 13 April 2020

\begin{abstract}
Eryngium alpinum L. is a high-value herb and a source of important compounds that include phenolics, triterpenoid saponins, and essential oils. The present report indicates successful micropropagation of this species. In our study, medium supplemented with BAP $2.0 \mathrm{mg} / \mathrm{L}$, IAA $1.0 \mathrm{mg} / \mathrm{L}$, and $\mathrm{GA}_{3} 1.0 \mathrm{mg} / \mathrm{L}$ was found to be the most suitable for long-term culture and for effective proliferation, irrespective of the passage number. Roots induction, without basal callus formation, was observed when individual microshoots were placed on Murashige \& Skoog medium augmented with auxin, and formation was the most advantageous in the presence of NAA alone or when combined with IAA or IBA. The encapsulated propagules were tested for their capability to endure different storage periods under low temperature. Therefore, we developed an efficient method for synseeds production by encapsulation of axillary buds in the sodium alginate matrix, storage for 2, 4, and 6 months, as well as the regeneration process. The maximum regeneration rate of $74 \% \pm 2.72 \%$ was observed for axillary buds encapsulated in $4 \%$ sodium-alginate complexed with $300 \mathrm{mM}$ calcium chloride after 2 months of storage at low temperature. This is the first report on E. alpinum micropropagation and somatic seeds production.
\end{abstract}

Keywords: alpine eryngo; protected species; clonal propagation; plant growth regulators; somatic seeds production and storage

\section{Introduction}

Eryngium alpinum L. in the Apiaceae family is protected by Annex II of the Habitats Directive; Appendix I of the Convention on the Conservation of European Wildlife and Natural Habitats; European Habitat Directive Natura 2000; and the national red lists [1,2]. The International Union for the Conservation of Nature (IUCN) classified it as vulnerable [3]. Bad harvesting management, collection for ornamental and commercial use, and the influence of changes in habitats and climate have led to decreases in population, extinction of endangered species, and destruction of natural resources [4]. This alarming situation is raising questions concerning special efforts that should be made to protect plant populations.

Due to the protection status of this taxon, it is not possible to harvest the raw material from natural sites. Conventional propagation by seeds of this species is also difficult because seeds fail to germinate due to a prolonged period of dormancy. Therefore, in vitro cultures can become an alternative source of raw material and allow for the generation of large numbers of propagules from a minimum amount of initial plant material from the natural habitat. The use of in vitro techniques in 
germplasm conservation is increasing and has been successfully applied to conservation of several rare and endangered species, both for propagation and for long-term storage. Micropropagation as well as somatic seeds are considered to have importance for rapid propagation and ex situ conservation of rare, endemic, and endangered medicinal plants [5]. In vitro cultures bring several advantages: They enable continuous production of uniform biomass from rare and protected plants independent of climatic and environmental conditions. Moreover, plant biomass with good biotechnological parameters may become the material for phytochemical and biological research without the need to deplete natural sites [6].

E. alpinum have been examined to a small extent so far. In the organs of intact plants, the presence of several phenolic acids [7-9], flavonoids [8-10], and essential oil were detected [11]. Chlorogenic acid, rosmarinic acid, and its derivative $\mathrm{R}-(+)-3^{\prime} \mathrm{O}-\beta-\mathrm{D}$-glucopyranosyl rosmarinic acid were found in the root ethanolic extract [7]. 3,4-Dihydroxyphenylacetic, chlorogenic, isochlorogenic, and rosmarinic acids were detected in the methanolic extract of basal leaves [8,9]. Two major flavonoids, kaempferol and quercetin, were found in the aerial part in the study of Crowden et al. [10] whereas isoquercetin was detected in basal leaves in the research of Kikowska et al. [8,9]. The main constituents identified by GC-FID and GC/MS in the essential oils of E. alpinum isolated by hydrodistillation of the aerial parts of the plant were caryophyllene oxide and $\alpha$-bisabolol from oxygenated sesquiterpenes as well as bicyclogermecrene and germacrene D [11].

The aim of the study was to establish an efficient and reproducible micropropagation protocol for alpine eryngo by applying the axillary bud proliferation technique as well as to establish the production of somatic seeds via alginate encapsulated axillary buds and organogenic calli for short-time storage of the endangered species. In the present study, the influence of different plant growth regulators in the agar-solidified media on shoot multiplication and root induction was studied. The effect of the type of a propagule, the bead composition, and the time of storage on regeneration potential of somatic seeds was investigated as well. These methods are especially important for Eryngium alpinum L. because it is of high value, its resources are limited based on the availability of plants, and it is difficult to grow. Due to the establishment of in vitro and ex situ collections, multiplication of the desired species may be used to obtain raw material for secondary metabolites production.

To the authors' best knowledge, there are no other reports on E. alpinum micropropagation and somatic seeds production. Alpine eryngo was introduced into in vitro cultures and shoot biomass was cultured in different systems: solid and liquid as well as stationary and agitated, which were previously phytochemically investigated by our team $[8,9]$.

\section{Results and Discussion}

Eryngium alpinum L. was introduced into in vitro cultures and the capacity to produce new shoots cultured on the media supplemented with different phytohormones was investigated [8]. Moreover, the suitable systems for E. alpinum shoot multiplication were examined [9]. Although the liquid culture systems were reported to be a favorable method for in vitro shoot multiplication, characterized by the possibility of extension for industrial production [12], the development of shoots was relatively high for this species, but shoots were fragile and deformed [9].

The limitation of seed production, endogenous morphological dormancy of seeds, and the low germination rate make generative propagation of this species very inefficient for this taxon $[4,13]$. For this reason, the small fragments with lateral buds, after disinfection, were the source of explants for the biotechnological experiments.

Growth and the multiplication rate of E. alpinum shoots were greatly influenced by the chemical nature of the medium (Table 1). 
Table 1. The effects of tested plant growth regulators on Eryngium alpinum L. growth parameters.

\begin{tabular}{|c|c|c|c|c|c|}
\hline \multicolumn{3}{|c|}{ MS Medium Supplementation } & \multicolumn{3}{|c|}{ Growth Parameters } \\
\hline \multicolumn{3}{|c|}{ Plant Growth Regulators } & \multirow[b]{2}{*}{ Induction (\%) } & \multirow[b]{2}{*}{$\begin{array}{c}\text { Shoot No. } \\
\text { /Explant } \pm \text { SE }\end{array}$} & \multirow[b]{2}{*}{$\begin{array}{l}\text { Shoot Length } \\
\text { (CM) } \pm \text { SE }\end{array}$} \\
\hline $\begin{array}{l}\text { Cytokinin } \\
(\mathrm{mg} / \mathrm{L})\end{array}$ & $\begin{array}{l}\text { Auxin } \\
(\mathrm{mg} / \mathrm{L})\end{array}$ & $\begin{array}{l}\text { Gibberellin } \\
\text { (mg/L) }\end{array}$ & & & \\
\hline & & & \multicolumn{3}{|c|}{ Sixth Subculture } \\
\hline BAP [2.0] & IAA [1.0] & $\mathrm{GA}_{3}[2.0]$ & 100 & $4.70 \pm 0.08^{g}$ & $3.87 \pm 0.22^{b}$ \\
\hline BAP [2.0] & IAA [1.0] & $\mathrm{GA}_{3}[1.0]$ & 100 & $24.10 \pm 1.35^{\mathrm{a}}$ & $2.12 \pm 0.05^{\mathrm{e}}$ \\
\hline BAP [1.0] & IAA $[0.5]$ & $\mathrm{GA}_{3}[1.0]$ & 100 & $13.70 \pm 0.70 \mathrm{dc}$ & $2.05 \pm 0.15^{\mathrm{e}}$ \\
\hline BAP [0.5] & IAA [0.5] & $\mathrm{GA}_{3}[0.5]$ & \multicolumn{3}{|c|}{ Twelfth Subculture } \\
\hline BAP [2.0] & IAA [1.0] & $\mathrm{GA}_{3}[2.0]$ & 100 & $3.50 \pm 0.28^{g}$ & $4.57 \pm 0.13^{\mathrm{a}}$ \\
\hline BAP [2.0] & IAA [1.0] & $\mathrm{GA}_{3}[1.0]$ & 100 & $18.90 \pm 0.80^{b}$ & $2.23 \pm 0.09 \mathrm{e}$ \\
\hline BAP [1.0] & IAA $[0.5]$ & $\mathrm{GA}_{3}[1.0]$ & 100 & $15.20 \pm 0.63^{c}$ & $2.31 \pm 0.04 \mathrm{e}^{\mathrm{e}}$ \\
\hline BAP [0.5] & IAA [0.5] & $\mathrm{GA}_{3}[0.5]$ & 100 & $8.10 \pm 0.48^{\mathrm{e}}$ & $3.80 \pm 0.08^{b}$ \\
\hline & & & \multicolumn{3}{|c|}{ Eighteenth Subculture } \\
\hline BAP [2.0] & IAA [1.0] & $\mathrm{GA}_{3}[2.0]$ & 100 & $5.40 \pm 0.58^{\mathrm{fg}}$ & $3.43 \pm 0.01^{\mathrm{c}}$ \\
\hline BAP [2.0] & IAA [1.0] & $\mathrm{GA}_{3}[1.0]$ & 100 & $25.10 \pm 1.38^{a}$ & $2.16 \pm 0.05^{\mathrm{e}}$ \\
\hline BAP [1.0] & IAA $[0.5]$ & $\mathrm{GA}_{3}[1.0]$ & 100 & $15.10 \pm 1.19^{\mathrm{c}}$ & $2.09 \pm 0.03^{\mathrm{e}}$ \\
\hline $\mathrm{BAP}[0.5]$ & IAA $[0.5]$ & $\mathrm{GA}_{3}[0.5]$ & 80 & $5.60 \pm 0.16^{\mathrm{fg}}$ & $4.08 \pm 0.09^{b}$ \\
\hline & & & \multicolumn{3}{|c|}{ Twenty Fourth Subculture } \\
\hline BAP [2.0] & IAA [1.0] & $\mathrm{GA}_{3}[2.0]$ & 80 & $5.20 \pm 0.29 \mathrm{fg}$ & $4.76 \pm 0.08^{a}$ \\
\hline BAP [2.0] & IAA [1.0] & $\mathrm{GA}_{3}[1.0]$ & 90 & $20.10 \pm 0.74^{b}$ & $2.08 \pm 0.04^{\mathrm{e}}$ \\
\hline BAP [1.0] & IAA $[0.5]$ & $\mathrm{GA}_{3}[1.0]$ & 100 & $12.50 \pm 1.45^{\mathrm{d}}$ & $3.01 \pm 0.03^{d}$ \\
\hline $\mathrm{BAP}[0.5]$ & IAA [0.5] & $\mathrm{GA}_{3}[0.5]$ & 100 & $5.60 \pm 0.31 \mathrm{fg}$ & $3.42 \pm 0.04^{c}$ \\
\hline
\end{tabular}

BAP: 6-benzylamninopurine, IAA: indolile-3-acetic acid, $\mathrm{GA}_{3}$ : gibberellic acid. Mean values within a column with the same letter are not significantly different at $p=0.05$ (Duncan's multiple range test).

It is known that 6-benzylaminopurine (BAP) is a highly effective regulator of in vitro morphogenesis. It is also well documented that cytokinins, particularly BAP, reduce the apical meristem dominance and stimulate axillary shoot multiplication in numerous species. The need to optimize the concentrations of cytokinins is critical because both the higher and lower concentrations of cytokinins are less effective in new shoot formation [14]. In accordance with our earlier publication [8] aimed at screening for the possibility of in vitro-derived shoots as a good source of phenolic compounds, new shoots developed best not in the presence of BAP alone but with BAP in combination with IAA at half of the BAP concentration. Therefore, in this study, different concentrations of these two regulators of plant growth and development were used in the systems in which the cytokinin concentration was the same or twice as high as that of auxin. Gibberellic acid $\left(\mathrm{GA}_{3}\right)$, the most common gibberellin applied, was used for inducement of shoot elongation. In our study, the medium supplemented with BAP $2.0 \mathrm{mg} / \mathrm{L}, \mathrm{IAA} 1.0 \mathrm{mg} / \mathrm{L}$, and GA $1.0 \mathrm{mg} / \mathrm{L}$ was found to be the most suitable for long-term culture of E. alpinum, followed by BAP $1.0 \mathrm{mg} / \mathrm{L}$, IAA $0.5 \mathrm{mg} / \mathrm{L}$, and $\mathrm{GA}_{3} 1.0 \mathrm{mg} / \mathrm{L}$ for effective multiplication, irrespective of the passage number (Table 1 ). Shoots grew vigorously and did not show any signs of vitrification or callusing at the base, irrespective of the plant growth regulators (PGRs) used (Figure 1). The higher multiplication ratio for this species was $18.09 \pm 1.43-25.12 \pm 2.12$ depending on subculture, but during several passages proved to be the most efficient (Table 1). In the case of E. planum, the highest mean number of shoots developed from axillary buds was $15.58 \pm 0.54-17.10 \pm 0.60$ shoots depending on the Murashige \& Skoog culture media: $\mathrm{MS}+\mathrm{BAP} 1.0 \mathrm{mg} / \mathrm{L}+\mathrm{IAA} 1.0 \mathrm{mg} / \mathrm{L}$ or $\mathrm{MS}+\mathrm{BAP} 1.0 \mathrm{mg} / \mathrm{L}+\mathrm{IAA} 0.1 \mathrm{mg} / \mathrm{L}$ [15]. For E. campestre, more shoots $(13.30 \pm 3.73)$ were obtained when cultured on the same media [16]. The efficiency of shoot multiplication for E. maritimum varied between $1.2 \pm 0.20$ and $4.4 \pm 0.24$ shoots per explant on the different media variants [17]. 


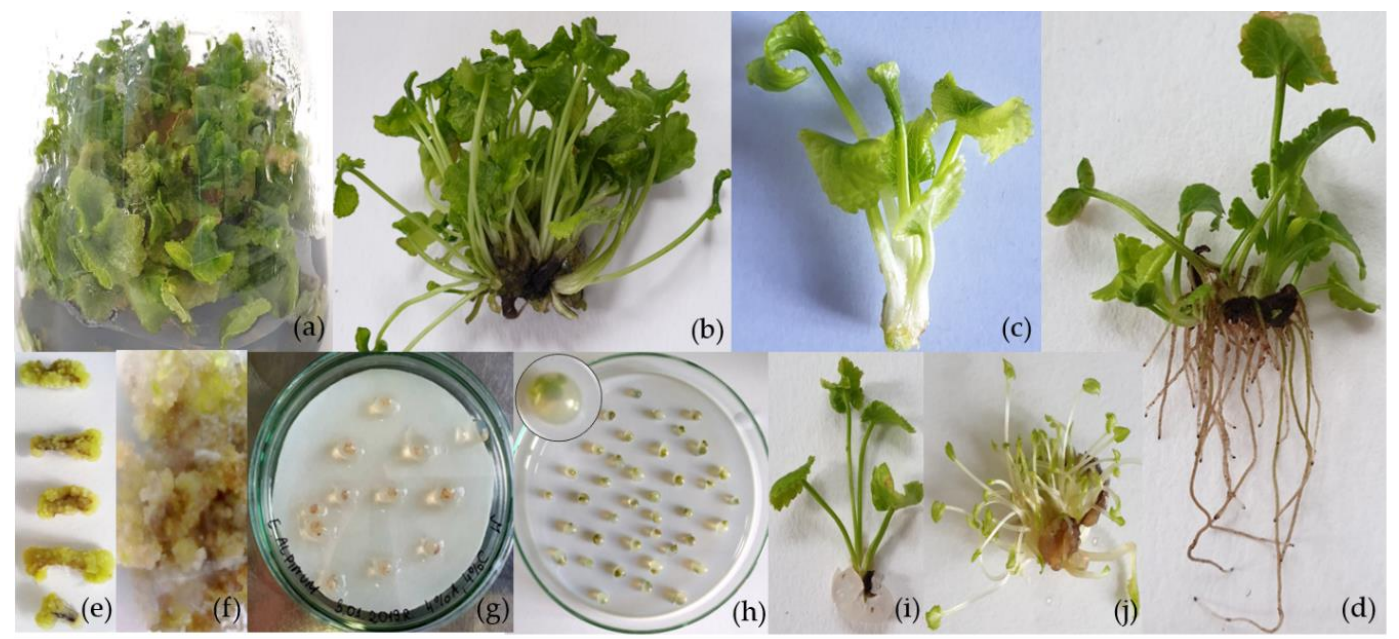

Figure 1. Micropropagation and somatic seeds production of E. alpinum L. (a) shoots multiplied by axillary buds development; (b) multiplied shoots; (c) single shoot before root induction; (d) plantlets with developed roots; (e) leaf-derived callus; (f) organogenic callus; (g) callus encapsulated; (h) axillary buds encapsulated; (i) shoot developed from axillary buds encapsulated; (j) shoots recovered from organogenic callus encapsulated.

It was observed in our previous studies [8,9] that, contrary to other related Eryngium species, E. planum [15], E. campestre [16], and E. maritimum [17], roots of alpine eryngo did not spontaneously occur on the media that were intended for shoot multiplication and which were characterized by the higher cytokinin concentration or the equal concentration of cytokinin and auxin. Application of BAP, even in the optimum concentrations, can inhibit subsequent root initiation [18]. In addition, the control medium, without phytohormones, was of little benefit for root induction and development, and the addition of auxins significantly affected rhizogenesis. In vitro-multiplied shoots induced roots in a way that depended on the type of auxin and their combination (Figure 1, Table 2).

Table 2. The effect of various types of auxins supplementing Murashige \& Skoog media on root induction and development of Eryngium alpinum L. shoots after 40 days of culture.

\begin{tabular}{cccc}
\hline Auxin(s) (1.0 mg/L) & Induction (\%) & Mean No. of Roots \pm SE & Mean Root Length \pm SE \\
\hline- & 50 & $1.4 \pm 0.64^{\mathrm{e}}$ & $1.96 \pm 0.17^{\mathrm{cd}}$ \\
IAA & 100 & $2.9 \pm 0.86^{\mathrm{de}}$ & $2.36 \pm 0.12^{\mathrm{a}}$ \\
IBA & 100 & $7.5 \pm 2.23^{\mathrm{d}}$ & $1.77 \pm 0.07^{\mathrm{cd}}$ \\
NAA & 100 & $27.4 \pm 1.35^{\mathrm{b}}$ & $0.61 \pm 0.04^{\mathrm{b}}$ \\
2,4-D & 100 & $15.00 \pm 2.69^{\mathrm{c}}$ & $1.79 \pm 0.06^{\mathrm{cd}}$ \\
Dic & 100 & $3.00 \pm 1.53^{\mathrm{de}}$ & $1.68 \pm 0.12^{\mathrm{d}}$ \\
Pic & 0 & $0.00 \pm 0.00^{\mathrm{e}}$ & $0.00 \pm 0.00^{\mathrm{e}}$ \\
IAA + IBA & 100 & $20.2 \pm 2.28^{\mathrm{c}}$ & $2.09 \pm 0.05^{\mathrm{a}}$ \\
IAA + NAA & 100 & $34.5 \pm 2.04^{\mathrm{a}}$ & $0.80 \pm 0.04^{\mathrm{b}}$ \\
IBA + NAA & 100 & $28.9 \pm 2.79^{\mathrm{b}}$ & $0.90 \pm 0.04^{\mathrm{b}}$ \\
\hline
\end{tabular}

2,4-D: 2,4-dichlorophenoxyacetic acid, Dic: (Dicamba) 3,6-dichloro-2-metoxybenzoic acid, IAA: indolile-3-acetic acid, IBA: indolile-3-butyric acid, NAA: 1-naphthaleneacetic acid, Pic: (Picloram) 4-amino-3,5,6-trichloro-2-pyridinecarboxylic acid. Mean values within a column with the same letter are not significantly different at $p=0.05$ (Duncan's multiple range test).

It can be concluded from the results presented in Table 2 that the addition of individual auxins to the rooting medium resulted in a different explant response. Supplementation of MS medium with picloram did not affect the appearance of roots, and when considering that roots were formed on the auxin-free media, it can be concluded that picloram inhibited their formation. The best type of auxin added to the medium was NAA, which induced on average 27 roots per shoot. Roots were characterized by similar morphology as those observed for E. planum, E. campestre, and E. maritimum in 
the presence of NAA: relatively thick and dark, initially short. However, unlike the compared species, callus did not form at the base of shoots or on the induced roots of E. alpinum. Profusely branched roots observed for micropropagated plantlets of E. planum, E. campestre, and E. maritimum as a result of IBA supplementation were not observed for E. alpinum [15-17]. Another effective auxin was 2,4-D and under its influence an average of 15 roots formed per cultured explant. Combinations of auxins were shown to be highly beneficial in the process of shoot rooting. It was observed that combinations inducing the highest number of roots (almost 29 and 35 per shoot) contained the addition of NAA. In previous studies on micropropagation of other Eryngium species, no auxin combination was used in the rooting stage of shoots.

The survival rate for clonally propagated E. alpinum was relatively low compared to other Eryngium species investigated by our team [15-17]. Sixty percent (36 plantlets) of rooted plants survived after being transplanted in the pots and 39\% (14 plantlets) in the soil. In vitro micropropagated plants were morphologically uniform, vigorous, and had well-developed roots. No detectable differences in growth characteristics were observed between clonal propagated plants and intact plants.

In the present work, a combination of Dic $1.0 \mathrm{mg} / \mathrm{L}$ and TDZ $1.0 \mathrm{mg} / \mathrm{L}$ supported E. alpinum callus induction. With the aim of inducing shoot bud organogenesis, the callus obtained was placed on MS medium supplemented with BAP $1.0 \mathrm{mg} / \mathrm{L}$, IAA $1.0 \mathrm{mg} / \mathrm{L}$, and GA $1.0 \mathrm{mg} / \mathrm{L}$. Finally, organogenic calli provided valuable material for short-term storage of somatic seeds.

Formation of beads with appropriate stability and hardness is of key importance for producing somatic seeds: very hard beads limit the regeneration ability, while soft beads dissolve without protecting the encapsulated propagules. The type of explant, the concentrations of sodium alginate (SA) and calcium chloride (CC), and complexation duration were studied for E. alpinum synseeds in this experiment (Table 3 ).

Table 3. The influence of the type of a propagule, the bead composition, as well as storage duration $\left(4{ }^{\circ} \mathrm{C}\right)$ on somatic seeds formation of Eryngium alpinum $\mathrm{L}$.

\begin{tabular}{cccc}
\hline Propagules & Sodium Alginate & Calcium Chloride & Bead Characteristic \\
\hline Axillary buds & $2 \%$ & $100 \mathrm{mM}$ & Too soft to handle \\
Axillary buds & $2 \%$ & $200 \mathrm{mM}$ & Too soft to handle \\
Axillary buds & $2 \%$ & $300 \mathrm{mM}$ & Too soft to handle \\
Axillary buds & $3 \%$ & $100 \mathrm{mM}$ & Formed tails \\
Axillary buds & $3 \%$ & $200 \mathrm{mM}$ & Formed tails \\
Axillary buds & $3 \%$ & $300 \mathrm{mM}$ & Too squashy \\
Axillary buds & $4 \%$ & $100 \mathrm{mM}$ & Deformed and isodiametric beads \\
Axillary buds & $4 \%$ & $200 \mathrm{mM}$ & Deformed and isodiametric beads \\
Axillary buds & $4 \%$ & $300 \mathrm{mM}$ & Isodiametric beads \\
Organogenic callus & $2 \%$ & $100 \mathrm{mM}$ & Too soft to handle \\
Organogenic callus & $2 \%$ & $200 \mathrm{mM}$ & Too soft to handle \\
Organogenic callus & $2 \%$ & $300 \mathrm{mM}$ & Too soft to handle \\
Organogenic callus & $3 \%$ & $100 \mathrm{mM}$ & Formed tails \\
Organogenic callus & $3 \%$ & $200 \mathrm{mM}$ & Formed tails \\
Organogenic callus & $3 \%$ & $300 \mathrm{mM}$ & Too squashy \\
Organogenic callus & $4 \%$ & $100 \mathrm{mM}$ & Deformed and isodiametric beads \\
Organogenic callus & $4 \%$ & $200 \mathrm{mM}$ & Deformed and isodiametric beads \\
Organogenic callus & $4 \%$ & $300 \mathrm{mM}$ & Isodiametric beads \\
\hline
\end{tabular}

Out of the three different concentrations of SA $(2 \%, 3 \%, 4 \%)$ and the three concentrations of CC $(100,200,300 \mathrm{mM})$ evaluated to develop the encapsulation matrix, $4 \%$ SA and $100 \mathrm{mM} \mathrm{CC}$ were the most appropriate for beads production and somatic seeds storage. The lower concentrations resulted in a weak structure, non-round shape of beads in nature, and poorly-coated propagules, which resulted in browning. Encapsulation with $4 \%$ SA and $100 \mathrm{mM} \mathrm{CC}$ was found to be very effective in maintaining the viability of the propagules and regeneration potential of plantlets. 
Axillary buds of in vitro-raised plants as well as ogranogenic calli were used as the propagules for encapsulation (Figure 1, Table 4). After storage, regardless of the number of weeks, encapsulated axillary buds showed the earliest response after 14 days compared to clumps of calli, which initially regenerated shoots after 24 days. Generally, axillary buds were more effective explants in regenerating shoots and then roots than were calli. The maximum regeneration rate of $74 \% \pm 2.72 \%$ was observed for axillary buds encapsulated in $4 \%$ sodium-alginate with $30 \mathrm{~min}$ complexation with $300 \mathrm{mM}$ calcium chloride after 2 months of storage at low temperature. Somatic seeds prepared from calli coated in $4 \% \mathrm{SA}$ and $300 \mathrm{mM} \mathrm{CC}$ exhibited the lowest regeneration rate $(15 \% \pm 0.71 \%)$ after 6 months of low-temperature storage. The regeneration rate, regardless of explants used, subsequently decreased with the increased duration (Table 4). In the study, a rupture of the encapsulation matrix during storage was not observed. Instead, in contrast to axillary buds, the callus fragments turned yellowish with the increase in storage duration.

Table 4. The influence of the type of explant and storage duration $\left(4^{\circ} \mathrm{C}\right)$ on recovery of the encapsulated propagules of Eryngium alpinum L.

\begin{tabular}{cccccc}
\hline Propagules & $\begin{array}{c}\text { Sodium } \\
\text { Alginate }\end{array}$ & $\begin{array}{c}\text { Calcium } \\
\text { Chloride }\end{array}$ & $\begin{array}{c}\text { Storage } \\
\text { Duration }\end{array}$ & $\begin{array}{c}\text { Survival } \\
\text { Percentage }\end{array}$ & $\begin{array}{c}\text { Recovery } \\
\text { Percentage }( \pm \text { SE) }\end{array}$ \\
\hline Axillary buds & $4 \%$ & $300 \mathrm{mM}$ & 0 months & 100 & $100^{\mathrm{m}} \pm 0.00^{\mathrm{a}}$ \\
Axillary buds & $4 \%$ & $300 \mathrm{mM}$ & 2 months & 100 & $74 \pm 2.08^{\mathrm{b}}$ \\
Axillary buds & $4 \%$ & $300 \mathrm{mM}$ & 4 months & 90 & $56 \pm 1.83^{\mathrm{c}}$ \\
Axillary buds & $4 \%$ & $300 \mathrm{mM}$ & 6 months & 60 & $42 \pm 1.04^{\mathrm{d}}$ \\
Organogenic callus & $4 \%$ & $300 \mathrm{mM}$ & 0 months & 80 & $46 \pm 0.90^{\mathrm{e}}$ \\
Organogenic callus & $4 \%$ & $300 \mathrm{mM}$ & 2 months & 60 & $32 \pm 0.97^{\mathrm{f}}$ \\
Organogenic callus & $4 \%$ & $300 \mathrm{mM}$ & 4 months & 40 & $26 \pm 0.76^{\mathrm{g}}$ \\
Organogenic callus & $4 \%$ & $300 \mathrm{mM}$ & 6 months & 20 & $15 \pm 0.44^{\mathrm{h}}$ \\
\hline
\end{tabular}

Mean values within a column with the same letter are not significantly different at $p=0.05$ (Duncan's multiple range test).

Somatic seeds production of a wide range of important endangered and protected species is considered an effective way to support their conservation [19-21].

The confirmation of genome size stability is of importance during in vitro plants propagation. In our study, the 2C DNA content of E. alpinum established in different plant material, namely leaves from shoots developed from axillary buds as well as regenerated from calli, encapsulated propagules, and in calli, was similar and ranged from 2.32 to $2.43 \mathrm{pg} / 2 \mathrm{C}$ (Table 5). The results concerning genome size stability were notably consistent with our previous studies on other Eryngium species [15-17].

Table 5. The nuclear DNA content in leaves of micropropagated plantlets and calli of Eryngium alpinum L.

\begin{tabular}{cc}
\hline Plant Material & DNA Content (PG/2C) \pm SE \\
\hline Leaf of shoot culture at passage 6 & $2.35 \pm 0.01 \mathrm{~ns}$ \\
Leaf of shoot culture at passage 12 & $2.35 \pm 0.01$ \\
Leaf of shoot culture at passage 18 & $2.35 \pm 0.00$ \\
Leaf of shoot culture at passage 24 & $2.32 \pm 0.01$ \\
Callus & $2.36 \pm 0.01$ \\
Leaf of callus-derived shoots & $2.43 \pm 0.04$ \\
Leaf of encapsulated callus-derived shoots & $2.35 \pm 0.01$ \\
Leaf of encapsulated bud-derived shoots & $2.34 \pm 0.01$ \\
\hline
\end{tabular}

ns-no significant differences at $p=0.05$ (Duncan's multiple range test). 


\section{Materials and Methods}

\subsection{The Plant Material}

Young individuals of Eryngium alpinum L. were collected from the Botanical Garden of Adam Mickiewicz University in Poznań, in September 2017. The voucher specimen was deposited in the Department of Pharmaceutical Botany and Plant Biotechnology Poznań University of Medical Sciences under the number H-AP-2017-102. Primary explants, shoot fragments with lateral buds, were surface disinfected according to the procedure adopted by [8]. Briefly, explants were disinfected with $50 \%(v / v)$ commercial bleach solution with $3.3 \%$ active calcium hypochlorite and 2-3 drops of Tween 80 for 5 min.

\subsection{The Culture Media and Conditions}

Aseptic explants were placed in Erlenmeyer flasks with $50 \mathrm{~mL}$ of solidified MS medium [22] with PGRs, benzylaminopurine (BAP; Sigma-Aldrich, Saint Louis, USA), indolile-3-acetic acid (IAA; Sigma-Aldrich, Saint Louis, MO, USA), and gibberellic acid (GA 3 ; Sigma-Aldrich, Saint Louis, MO, USA), at the concentration of $1.0 \mathrm{mg} / \mathrm{L}$ [8]. The media were autoclaved at $121{ }^{\circ} \mathrm{C}$, at a pressure of $0.1 \mathrm{MPa}$ for $20 \mathrm{~min}$. The cultures were grown under artificial light at $55 \mu \mathrm{mol} / \mathrm{m}^{2} \mathrm{~s}(16 \mathrm{~h}$ light $/ 8 \mathrm{~h} \mathrm{dark}$ photoperiod) and at temperature of $21^{\circ} \mathrm{C} \pm 2{ }^{\circ} \mathrm{C}$.

\subsection{Micropropagation: Shoot Multiplication}

Shoots were multiplied via the axillary branching method [23] on MS medium solidified with $7.6 \mathrm{~g} / \mathrm{L}$ agar and enriched with BAP $(2.0 \mathrm{mg} / \mathrm{L}, 1.0 \mathrm{mg} / \mathrm{L}$ or $0.5 \mathrm{mg} / \mathrm{L})$, IAA $(1.0 \mathrm{mg} / \mathrm{L}$ or $0.5 \mathrm{mg} / \mathrm{L})$, and $\mathrm{GA}_{3}(2.0 \mathrm{mg} / \mathrm{L}, 1.0 \mathrm{mg} / \mathrm{L}$ or $0.5 \mathrm{mg} / \mathrm{L})$ for 24 passages. The $250 \mathrm{~mL}$ Erlenmeyer flasks with $50 \mathrm{~mL}$ of the medium were used. After 40 days of culture, the percentage of explant-regenerated shoots, the number of new shoots per explant and their length were measured. The experiments were repeated three times for 30 explants at different time intervals.

\subsection{Micropropagation: Root Induction}

In vitro-multiplied shoots of c.a. $2-3 \mathrm{~cm}$ (from 12th to 18 th subculture) were transferred to MS solidified medium supplemented with a single auxin: indolile-3-acetic acid (IAA), indolile-3-butyric acid (IBA, Sigma-Aldrich, Saint Louis, MO, USA), 1-naphthaleneacetic acid (NAA, Sigma-Aldrich, Saint Louis, MO, USA), 2,4-dichlorophenoxyacetic acid (2,4-D, Sigma-Aldrich, Saint Louis, MO, USA), 4-amino-3,5,6-trichloro-2-pyridinecarboxylic acid (picloram, Pic, Sigma-Aldrich, Saint Louis, MO, USA), 3,6-dichloro-2-metoxybenzoic acid (dicamba, Dic, Sigma-Aldrich, Saint Louis, MO, USA), or their combination IAA + IBA, IAA + NAA, IBA + NAA, each at the concentration of $1.0 \mathrm{mg} / \mathrm{L}$. The glass tubes with $30 \mathrm{~mL}$ of the medium were used. The number of roots per shoot and their length were recorded after 40 days. The experiments were repeated three times for 10 explants at different time intervals.

Successfully rooted plantlets were removed from the rooting medium, washed thoroughly to remove adhering agar, and transferred to micro plastic pots of $5 \mathrm{~cm}$ height and $6 \mathrm{~cm}$ diameter containing a mixture of soil, vermiculite, and sand (1:1:1 v/v/v) and covered with translucent plastic cubs to ensure high humidity. The pots with in vitro propagated plantlets (60 individuals) were placed at room temperature $\left(23 \pm 2{ }^{\circ} \mathrm{C}\right)$ under normal day length conditions. The survival rate was recorded after 62 days and then the plantlets were transferred to the field (36 individuals).

\subsection{Organogenic Callus Induction and Proliferation}

Leaf explants of multiplied shoots were placed in $250 \mathrm{~mL}$ flasks containing $50 \mathrm{~mL}$ of the solidified MS basal medium with 3,6-dichloro-2-metoxybenzoic acid (dicamba, Dic $1.0 \mathrm{mg} / \mathrm{L}$ ) and thidiazuron (TDZ $1.0 \mathrm{mg} / \mathrm{L}$, Sigma-Aldrich, Saint Louis, MO, USA). Callus clumps observed after three weeks of culture on MS medium with Dic and TDZ were divided into clumps of about the same size $\left(1 \mathrm{~cm}^{2}\right)$ and transferred onto the regeneration MS media with the selected PGRs: BAP (1.0 mg/L), IAA (1.0 mg/L), 
and $\mathrm{GA}_{3}(1.0 \mathrm{mg} / \mathrm{L})$. Organogenic callus cultures were grown under the same light and temperature conditions as the shoot cultures developed from lateral buds.

\subsection{Synthetic Seed Production and Storage}

Axillary buds and organogenic calli of a $0.3-0.4 \mathrm{~cm}$ diameter were excised from in vitro cultures. For encapsulation, explants were plunged into the solution of sodium alginate and then into calcium chloride $\left(\mathrm{CaCl}_{2} \times 2 \mathrm{H}_{2} \mathrm{O}\right)$ for complexation. Somatic seeds were washed with sterile distilled water. The encapsulated propagules were placed in $90 \mathrm{~cm}$ diameter Petri dishes at $4{ }^{\circ} \mathrm{C}$ in darkness and after the storage time they were transferred to the growth chamber for recovery. MS medium supplemented with BAP $2.0 \mathrm{mg} / \mathrm{L}$, IAA $1.0 \mathrm{mg} / \mathrm{L}$, and $\mathrm{GA}_{3} 1.0 \mathrm{mg} / \mathrm{L}$ was used for plant regeneration of somatic seeds. The types of plant growth regulators and their concentrations were optimized through a separate experiment: shoot multiplication and callus proliferation.

In the first experiment, different concentrations of sodium alginate solution, $2 \%(w / v), 3 \%(w / v)$ or $4 \%(w / v)$, and calcium chloride, $100 \mathrm{mM}, 200 \mathrm{mM}$, and $300 \mathrm{mM}$, were tested. Different time periods $(20,30$, or $40 \mathrm{~min})$ for $\mathrm{Na}^{+} / \mathrm{Ca}^{2+}$ ion exchange in the calcium chloride solution were applied (no statistical differences were noted for the results, therefore they were not included in the article). In the second experiment, different storage times of somatic seeds (2, 4,6 months) placed in $90 \mathrm{~cm}$ diameter Petri dishes at $4{ }^{\circ} \mathrm{C}$ in darkness were tested. Each experiment was repeated three times for c.a. 40 explants.

\subsection{Genome Size Estimation}

Leaves of in vitro-multiplied shoots, shoots regenerated from calli, callus biomass, and leaves of shoots regenerated from the alginate-encapsulated propagules after storage were used for flow cytometric estimation of nuclear DNA content. A nuclei isolation buffer [24] supplemented with 1\% $(v / v)$ polyvinylpyrrolidone (PVP-10), propidium iodide (PI; $\left.50 \mu \mathrm{g} / \mathrm{cm}^{3}\right)$, and ribonuclease A $\left(50 \mu \mathrm{g} / \mathrm{cm}^{3}\right)$ was applied for sample preparation. Petunia hybrida $\mathrm{P} \times \operatorname{Pc} 6(2.85 \mathrm{pg} / 2 \mathrm{C}$; [25]) was used as an internal standard. For each sample, 5000-8000 nuclei were analyzed using a CyFlow SL Green flow cytometer (Partec $\mathrm{GmbH}$, Münster, Germany) equipped with a high-grade solid-state laser with green light emission at $532 \mathrm{~nm}$, a long-pass filter RG 590 E, DM 560 A, as well as with side (SSC) and forward (FSC) scatters, using linear amplification. FloMax software (Partec $\mathrm{GmbH}$, Münster, Germany) was applied for histogram evaluation. The analyses were replicated at least three times for each plant material. The coefficient of variation (CV) of G0/G1 peak of E. alpinum ranged from $3.2 \%$ to $4.6 \%$. The nuclear DNA content was calculated using the linear relationship between the ratio of the $2 \mathrm{C}$ peak positions E. alpinum/P. hybrida on a histogram of fluorescence intensities.

\subsection{The Statistical Analysis}

The obtained data were analyzed using a one-way analysis of variance (ANOVA) and the statistical significance was determined by Duncan's POST-HOC test ( $p$ value of 0.05 ). All the analyses were conducted using STATISCICA v. 13 (StatSoft Polska, Inc. 2015, Kraków, Poland).

\section{Conclusions}

The present report details the efficient protocol for Eryngium alpinum L. micropropagation from axillary bud development with the confirmed uniformity of genome size. Micropropagation and synseeds are encouraging methods for germplasm conservation of valuable and uniform raw material of endangered and protected species. Our study indicated that somatic seeds, artificially encapsulated with $4 \%$ sodium alginate and $300 \mathrm{mM}$ calcium chloride axillary buds, could be stored at $4{ }^{\circ} \mathrm{C}$ for 6 months without loss of viability and with high regeneration ability. 
Author Contributions: Conceptualization, M.K.; methodology, M.K..; validation, M.K., E.S.; formal analysis, M.K.; E.S.; investigation, M.K., E.S.; resources, M.K.; data curation, M.K., E.S.; writing—original draft preparation, M.K.; writing-review and editing, M.K., B.T., E.S.; visualization, M.K., B.T.; supervision, B.T.; project administration, M.K.; funding acquisition, M.K., B.T. All authors have read and agreed to the published version of the manuscript.

Funding: This research was funded by National Science Centre, Poland, grant number 2019/03/X/NZ7/01846.

Conflicts of Interest: The authors declare no conflict of interest.

\section{References}

1. Wyse-Jackson, P.S.; Akeroyd, J.R. Guidelines to Be Followed in the Design of Plant Conservation or Recovery Plans; Nature and Environment; Council of Europe: Strasbourg, France, 1994; p. 68.

2. Gygax, A.; Bernhardt, K.G.; Jogan, N.; Montagnani, C.; Gigot, G. Eryngium alpinum. In The IUCN Red List of Threatened Species; Version 2014.3; IUCN: Gland, Switzerland, 2013.

3. Gillot, P.; Garraud, L. Eryngium alpinum (L.). In Livre Rouge de la Flore Menacée; Museum National d'Histoire Naturelle: Paris, France; Conservatoire Botanique National de Porquerolles: Paris, France; Ministère de l’Environnement: Paris, France, 1995; p. 185.

4. Gaudeul, M.; Till-Bottraud, I. Reproductive ecology of the endangered Alpine species Eryngium alpinum L. (Apiaceae): Phenology, gene dispersal and reproductive success. Ann. Bot. 2004, 93, 711-721. [CrossRef] [PubMed]

5. Tasheva, K.; Kosturkova, G. Role of Biotechnology for protection of endangered medicinal plants. In Environmental Biotechnology—New Approaches and Perspective Applications; Petre, M., Ed.; Chapter 11; IntechOpen: London, UK, 2013.

6. Espinosa-Leal, C.A.; Puente-Garza, C.A.; García-Lara, S. In vitro plant tissue culture: Means for production of biological active compounds. Planta 2018, 248, 1-18. [CrossRef] [PubMed]

7. Le Claire, E.; Schwaiger, S.; Banaigs, B.; Stuppner, H.; Gafner, F. Distribution of a new rosmarinic acid derivative Eryngium alpinum L. and other Apiaceae. J. Agric. Food Chem. 2005, 53, 4367-4372. [CrossRef] [PubMed]

8. Kikowska, M.; Thiem, B.; Szopa, A.; Klimek-Szczykułowicz, M.; Rewers, M.; Sliwinska, E.; Ekiert, H. Comparative analysis of phenolic acids and flavonoids in shoot cultures of Eryngium alpinum L.-An endangered and protected species with medicinal value. Plant Cell Tissue Organ Cult. 2019, 139, 167-175. [CrossRef]

9. Kikowska, M.; Thiem, B.; Szopa, A.; Ekiert, H. Accumulation of valuable secondary metabolites: Phenolic acids and flavonoids in different in vitro systems of shoot cultures of the endangered plant species-Eryngium alpinum L. Plant Cell Tissue Organ Cult. 2020. [CrossRef]

10. Crowden, R.K.; Harborne, J.B.; Heywood, V.H. Chemosystematics of the Umbelliferae-A general survey. Phytochemistry 1969, 8, 1963-1984. [CrossRef]

11. Dunkic, V.; Vuko, E.; Bezic, N.; Kremer, D.; Ruscic, M. Composition and antiviral activity of the essential oils of Eryngium alpinum and E. amethystinum. Chem. Biodivers. 2013, 10, 1894-1902. [CrossRef] [PubMed]

12. Mehrotra, S.; Goel, M.K.; Kukreja, A.K.; Mishra, B.N. Efficiency of liquid culture systems over conventional micropropagation: A progress towards commercialization. Afr. J. Biotechnol. 2007, 6, 1484-1492. [CrossRef]

13. Njenga, J. Production of Eryngium. N.C. Flower Growers' Bull. 1995, 40, 9-11.

14. Müller, D.; Leyser, O. Auxin, cytokinin and the control of shoot branching. Ann. Bot. 2011, 107, $1203-1212$. [CrossRef] [PubMed]

15. Thiem, B.; Kikowska, M.; Krawczyk, A.; Więckowska, B.; Sliwinska, E. Phenolic acid and DNA contents of micropropagated Eryngium planum L. Plant Cell Tissue Organ Cult. 2013, 114, 197-206. [CrossRef]

16. Kikowska, M.; Thiem, B.; Sliwinska, E.; Rewers, M.; Kowalczyk, M.; Stochmal, A.; Długaszewska, J. Micropropagation of Eryngium campestre L. via shoot culture provides valuable uniform plant material with enhanced content of phenolic acids and antimicrobial activity. Acta Biol. Cracoviensia Bot. 2016, 58, 43-56. [CrossRef]

17. Kikowska, M.; Thiem, B.; Sliwinska, E.; Rewers, M.; Kowalczyk, M.; Stochmal, A.; Oleszek, W. The effect of nutritional factors and plant growth regulators on micropropagation and production of phenolic acids and saponins from plantlets and adventitious root cultures of Eryngium maritimum L. J. Plant Growth Regul. 2014, 33, 809-819. [CrossRef] 
18. Werbrouck, S.P.O.; van der Jeugt, B.; Dewitte, W.; Prinsen, E.; Van Onckeken, H.A.; Debergh, P.C. The metabolism of benzyladenine in S. floribundum Scott 'Petite' in relation to acclimatization problems. Plant Cell Rep. 1995, 14, 662-665. [CrossRef] [PubMed]

19. Kikowska, M.; Thiem, B. Alginate-encapsulated shoot tips and nodal segments in micropropagation of medicinal plants. A review. Herba Polonica 2011, 57, 45-57.

20. Chandana, B.C.; Kumari Nagaveni, H.C.; Heena, M.S.; Shashikala, S.K.; Lakshmana, D. Role of plant tissue culture in micropropagation, secondary metabolites production and conservation of some endangered medicinal crops. J. Pharmacogn. Phytochem. 2018, SP3, 246-251.

21. Saxena, A.; Shukla, M.; Saxena, P. Synthetic Seeds: Relevance to Endangered Germplasm Conservation In Vitro. In Synthetic Seeds; Faisal, M., Alatar, A., Eds.; Springer: Cham, Switzerland, 2019. [CrossRef]

22. Murashige, T.; Skoog, F. A revised medium for rapid growth and bioassays with tobacco cultures. Physiol. Plant. 1962, 15, 473-497. [CrossRef]

23. Ngezahayo, F.; Liu, B. Axillary bud proliferation approach for plant biodiversity conservation and restoration. Int. J. Biodivers. 2014, 2014, 727025. [CrossRef]

24. Galbraith, D.W.; Harkins, K.R.; Maddox, J.M.; Ayres, N.M.; Sharma, D.P.; Firoozabady, E. Rapid flow cytometric analysis of the cell cycle in intact plant tissues. Science 1983, 220, 1049-1051. [CrossRef] [PubMed]

25. Marie, D.; Brown, S.C. A cytometric exercise in plant histograms, with $2 \mathrm{C}$ values for 70 species. Biol. Cell. 1993, 78, 41-51. [CrossRef]

(C) 2020 by the authors. Licensee MDPI, Basel, Switzerland. This article is an open access article distributed under the terms and conditions of the Creative Commons Attribution (CC BY) license (http://creativecommons.org/licenses/by/4.0/). 